\title{
18-8 ステンレス鋼の変形応力に及ほす静水圧の影響
}

$$
\text { 小口 } \text { 醇 }^{*} \text { 吉田 進* }
$$

Atsushi Oguchi and Susumu Yoshida: Influence of High Hydrostatic Pressure on the Flow Stress of 18-8 Stainless Steel. An austenitic 18-8 stainless steel was tested in tension under hydrostatic pressure and the influence of hydrostatic pressure on its stress-strain behaviour was discussed. Tensile tests under constant pressures of $12000 \mathrm{~kg} / \mathrm{cm}^{2}$ and atmospheric pressure and tests during which the ambient pressure was changed from $12000 \mathrm{~kg} / \mathrm{cm}^{2}$ to atmospheric pressure and vice versa were carried out at room temperature. Also, the change in inductance of a coil wound around the specimen was measured to evaluate the amount of $\alpha$-martensite induced by plastic deformation. The results obtained are as follows : (1) Pressurizing at $12000 \mathrm{~kg} / \mathrm{cm}^{2}$ gives no effect on the stress-strain relation of annealed specimen at atmospheric pressure. (2) By the magnetic measurement, $\alpha$-martensite cannot be observed in the strain range less than about $10 \%$ strain. At a larger strain it begins to be induced and its amount increases with increasing strain by the same rate under both $12000 \mathrm{~kg} / \mathrm{cm}^{2}$ and atmospheric pressure. But $\varepsilon$-martensite is observed by X-ray diffraction when the specimen is deformed under $12000 \mathrm{~kg} / \mathrm{cm}^{2}$. (3) When the specimens are deformed under a constant pressure of $12000 \mathrm{~kg} / \mathrm{cm}^{2}$, the increase in flow stress as compared with that at atmospheric pressure is very large at the beginning of deformation, decreases with increasing strain, and then becomes almost constant (about $12 \%$ ) above about $15 \%$ strain or more. (4) When the ambient pressure is changed between atmospheric pressure and $12000 \mathrm{~kg} / \mathrm{cm}^{2}$ on the way of deformation, the flow stress changes 0 to $4 \%$.at small strains and, about $12 \%$ (pressure raising) and $19 \%$ (pressure releasing) at 30 to $40 \%$ strain. (5) The phenomena mentioned above in (3) and (4) can be explained by the fact that $\varepsilon$-martensite is induced rapidly at the beginning of deformation resulting in work-hardening under high hydrostatic pressure, while it easily transforms to $\alpha$-martensite under a low tensile stress at atmospheric pressure at large strains.

(Received January 21, 1972)

\section{I. 緒言}

18-8 ステンレス鋼は室温において塑性変形によりオー ステナイトからマルテンサイトに变態し，これが変形の挙 動に影響することが知られている(1).この変態は比体積変 化を伴うし，Ms 温度は静水圧によって変化することが明 らかにされている(2)ので，このよらな材料を静水圧下で変 形させると，その変形挙動は大気圧下に扑けるものにくら べてかなり異なるであろらと考えられる。 またこのような 相連を積極的に利用することによって，将来静水圧下の塑 性加工をこの種の材料の性能向上に役立てることができる かもしれない：ここではまずオーステナイト組織をもつ 18-8 ステンレス鋼試料を大気圧下，または $12000 \mathrm{~kg} / \mathrm{cm}^{2}$ 中で引張試験して応力ーひずみ曲線の圧力による変化を求 め, 従来の純金属について得られた結果と比較しながら検 討を加えた結果を報告する.

\section{II. 試料および実験方法}

実験に用いた材料は市販の 18-8 ステンレス鋼硬引線(直 径 $1 \mathrm{~mm}$ ) で,化学分析によると $\mathrm{Cr}: 18.09 \%, \mathrm{Ni}: 8.41 \%$ ，

* 金属材料技術研究所 (National Research Institute for Metals, Tokyo)

(1) D. C. Ludwigson and J. A. Berger : J. Iron Steel Inst., $207(1969), 63$.

(2) J.R.Patel and M.Cohen : Acta 'Met.,1 (1953), 531.
C : $0.08 \%$ であった. これを試料寸法に切断した後 $850^{\circ} \mathrm{C}$, $1 \mathrm{hr}$ 真空焼鈍して引張試験片とした。 このような材料を オーステナイト化するには一般に $1000^{\circ} \mathrm{C}$ 以上の温度から 急冷する。しかし本実験の場合，実験装置の関係から試料 の直径は $1 \mathrm{~mm}$ としたので結晶粒径が大きいと実験結果に ばらつきを生ずる危険があり，そのため $\mathrm{Cr}_{23} \mathrm{C}_{6}$ の溶解温 度(C: $0.08 \%$ において)の下限をえらんで上記の $850^{\circ} \mathrm{C}$, $1 \mathrm{hr}$ の条件を決定した。この場合, 結晶粒径は約 $0.01 \mathrm{~mm}$ であった．顕微鏡観察および磁性測定によれば試料は完全 にオーステナイト状態であった.

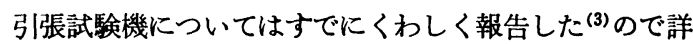
細な説明は省略するが，最高 $15000 \mathrm{~kg} / \mathrm{cm}^{2}$ までの任意の 一定圧力中で引張試験ができ，また試験中圧力を变えるこ ともできるものである.

これにより (i) $12000 \mathrm{~kg} / \mathrm{cm}^{2}$ の液圧処理による大気圧下 の応力-ひずみ曲線の変化，(ii)引張試験の途中で圧力を 大気圧から $12000 \mathrm{~kg} / \mathrm{cm}^{2}$ へ，あるいはその逆に変化させ たときの変形応力の変化, (iii) $12000 \mathrm{~kg} / \mathrm{cm}^{2}$ の静水压下 で引張試験をした場合の応力ーひずみ曲線の，大気圧下で のものに対する変化を求めた.

変形に伴らマルテンサイトの生成量は次のようにして推 定した. この材料の場合,オーステナイトは非磁性である

(3) 吉田, 小口：材料, 18(1969)，779 
が， $\alpha$ 一、ルテンサイトは磁性を有する，そこで $0.08 \mathrm{~mm}$ 直径の絹巻線で 300 ターンのコイルを作り，これに試料を 差込んでュイルのインダクタンスの変化をマックスウェル ブリッジで測定した，マルテンサイト量とインダクタンス の变化の量的な関係は求めなかったが，測定されたインダ クタンスの变化は，定性的にマルテンサイト量の变化の傾 向を表わしていると考えてよいであろう。

試験片の平行部の長さは $15 \mathrm{~mm}$, 引張速度は $0.5 \mathrm{~mm} /$ min とした。試験温度は室温である。

\section{III. 実 娩 結 果}

\section{1. 液王処理の効果}

試料に $12000 \mathrm{~kg} / \mathrm{cm}^{2}$ の静水压を $10 \mathrm{~min}$ 加之，そのま ま圧力を除去して大気生下で弓張試験した結果, その荷重一 伸び曲楾は瘔鈍したままのものとほとんぞ一致した。すな わちいわゆる液纴処理の効果は観察されなかった。オース テナイト相は面心立方晶構造であり，光学顕铛鏡によって る特に大きな介在物等の異相はみられなかったことから， この試料の場合は組織内に液圧処理効果の原因々なる弾性 的不連続性が存在せず, $12000 \mathrm{~kg} / \mathrm{cm}^{2}$ の静水压に上って も試料内部構造の非可逆的变化が生じなかったものと考元 られる。

\section{2. 示差印力法による引張試験}

Fig.1は $12000 \mathrm{~kg} / \mathrm{cm}^{2}$ の压力下で引張試験を開始し， その途中のあるひずみで变形を中断して除荷した後住力を 除去し，大気圧下で変形を再開したときの応力ーひずみ曲 線を示したものである．図中破線は大気圧下での試験に拉 ける応力ーひずみ曲線を示している，図にみられるように， $12000 \mathrm{~kg} / \mathrm{cm}^{2}$ 中でのひずみ量が小さい間は圧力変化に伴 い变形応力はわずかしか低下せず，はじぬから大気压下で 变形した場合より高いが, $12000 \mathrm{~kg} / \mathrm{cm}^{2}$ 中でのひずみ量 が大きくなると変形応力は大きく低下して，大気压下で変

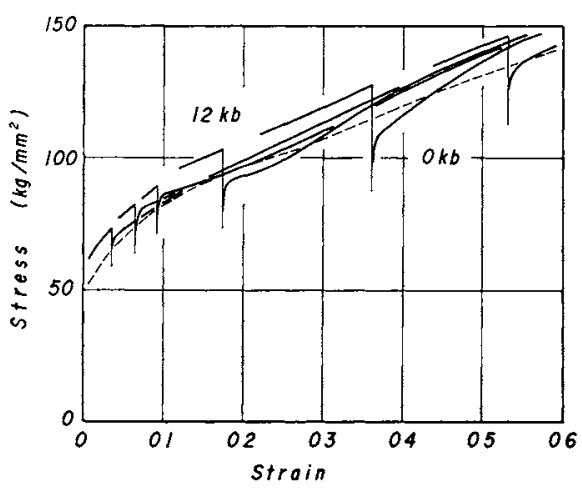

Fig.1 Stress-strain relations obtained on changing the ambient pressure from $12000 \mathrm{~kg} / \mathrm{cm}^{2}$ to atmospheric pressure on the way of tensile tests. Broken line represents the stressstrain relation at atmospheric pressure
形させた場合の値より低くなる。またいずれの場合にも大 気圧下での再負荷の際加工硬化が急激になる傾向がある が，約 $20 \%$ ひずメまで高静水圧中で变形させたものでは 変形再開時に一旦加工硬化がゆるやかになる様子がみられ る.Fig.2は Fig.1の場合と道に，はじぬ大気圧下で変形 し, 途中で圧力を $12000 \mathrm{~kg} / \mathrm{cm}^{2}$ に上げて変形を続けた時 の応力ーひずみ曲線を示するのである。をた Fig.3は上に 述べたよらな圧力变化化伴ら变形応力の变化を Figs.1, 2 の結果から変化の割合として求めて示したものである。こ れ炕上机沁力変化の傾向は圧力変化の方向(圧力上昇ま たは圧力降下にによらず類似であるがその大きさは压力降 下の場合の方が大きい，またひずみ約 $10 \%$ までは小さい

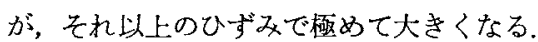

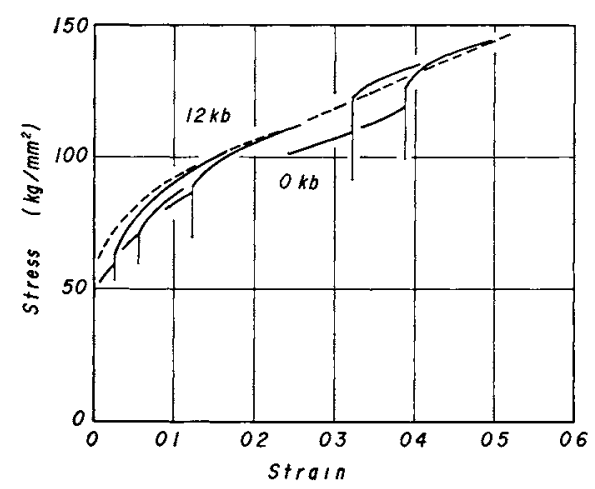

Fig.2 Stress-strain relations obtained on changing the ambient pressure from atmospheric pressure to $12000 \mathrm{~kg} / \mathrm{cm}^{2}$ on the way of tensile tests. Broken line represents the stress-strain relation under $12000 \mathrm{~kg} / \mathrm{cm}^{2}$

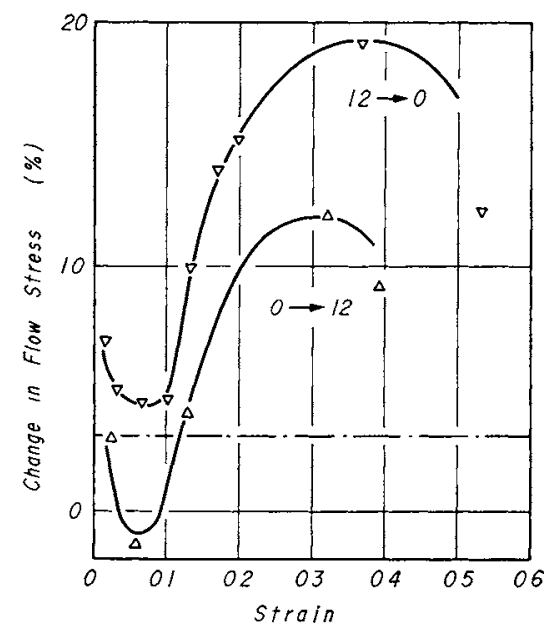

Fig.3 Change in flow stress on changing the ambient pressure from $12000 \mathrm{~kg} / \mathrm{cm}^{2}$ to atmospheric pressure $(\nabla)$ and from atmospheric pressure to $12000 \mathrm{~kg} / \mathrm{mm}^{2}(\Delta)$. Dot-dash line represents the change in shear modulus of the material presumed from the data by Bridgman 


\section{3. 一定圧力下での引張試験}

Fig.4 は大気圧下および $12000 \mathrm{~kg} / \mathrm{cm}^{2}$ 中で変形させた ときの応力ーひずみ曲線を示している. この結果から 12000 $\mathrm{kg} / \mathrm{cm}^{2}$ 中に护ける変形応力の大気圧下のものに対する增 加率を求めた結果を同じ図中に示す．この応力変化は変形 初期に大きく、ひずみの増加と共に减少し，約 $20 \%$ ひず み以降で約 $12 \%$ 程度の一定の值となる傾向を示す。

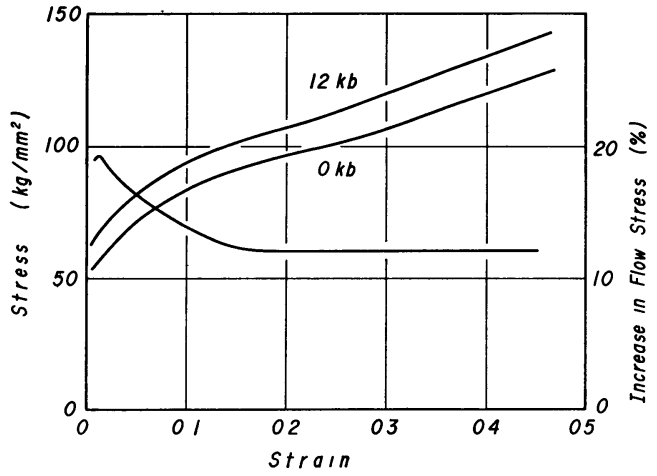

Fig.4 Stress-strain relations under $12000 \mathrm{~kg} / \mathrm{cm}^{2}$ and atmospheric pressure. Increase in flow stress under $12000 \mathrm{~kg} / \mathrm{mm}^{2}$ as compared with that at atmospheric pressure is also shown.

\section{4. 変形による $\boldsymbol{\alpha}$-マルテンサイトの生成}

焼鈍材を前述したコイル内にさし込み，試料を大気圧下 あるいは $12000 \mathrm{~kg} / \mathrm{cm}^{2}$ 中で変形させてそれに伴らインダ クタンスの变化 $(\Delta L)$ を測定した結果を Fig.5に示す。 こ の結果は $\alpha$-マルテンサイト量そのものを示してはいない が，その変化の傾向は表わしていると考えてょいであろ う.この結果によると,この試料の場合ひずみ $-\Delta L$ の関

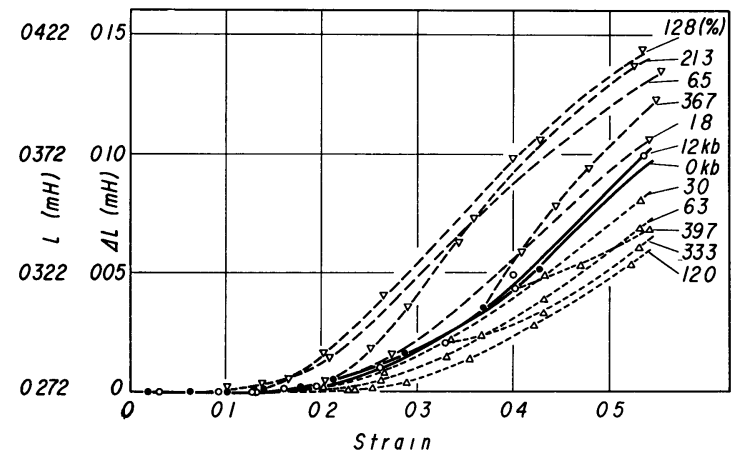

Fig.5 Change in inductance of a coil wound around the specimen as a function of tensile strain. Solid lines: under constant pressures of atmospheric pressure and $12000 \mathrm{~kg} / \mathrm{cm}^{2}$. Broken lines: the ambient pressure was released from $12000 \mathrm{~kg} / \mathrm{cm}^{2}$ to atmospheric pressure at strains indicated. Dotted lines : the ambient pressure was raised from atmospheric pressure to 12000 $\mathrm{kg} / \mathrm{cm}^{2}$
係には圧力による差がほとんどなかった，すなわち大気圧 下でも，また $12000 \mathrm{~kg} / \mathrm{cm}^{2}$ 中でも同一ひずみを与えると 汪湆同量の $\alpha$-マルテンサイトが生成されている，また， 伸び約 $10 \%$ までは $\alpha$-マルテンサイトはほとんど生じてい ない，同図に破線および点線で示したものは，変形の途中 で圧力をそれぞれ $12000 \mathrm{~kg} / \mathrm{cm}^{2}$ から大気圧へ，および大 気圧から $12000 \mathrm{~kg} / \mathrm{cm}^{2}$ へ変化させたときの測定結果であ

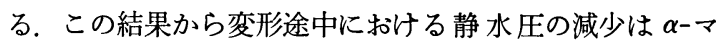
ルテンサイトの生成を促進し，その增加は $\alpha$-マルテンサ イトの生成を抑止することがわかる。

\section{X線回折による锤察}

大気圧下および $12000 \mathrm{~kg} / \mathrm{cm}^{2}$ の静水圧下で引張試験を 行なった試料について，X線回折によりデバイシェーラー 図形を撮影した，その結果， $\alpha$-マルテンサイトの生成につ いては前項の磁気測定と一致する結果が得られたが，その 他に静水圧下で約 $20 \%$ 变形した試料からはいわゆる ルテンサイトによると考えられる回折線が観察された.

\section{IV. 考察}

\section{1. 静水圧下の変形による $\varepsilon$ 相の生成}

18-8 ステンレス鋼を変形する場合，変形が進行するに したがい， $\alpha$-マルテンサイトが生成し，変形量と共に次第 にその量を増加する。 また，六方稠密格子の $\varepsilon$-マルテン サイトが少量ではあるが变形の初期から発生しあるひずみ 量で最大となりまた減少することが知られている(4)(5)。 こ の場合， $\alpha$-マルテンサイトはかならずオーステナイト $\rightarrow \varepsilon-$ マルテンサイト $\rightarrow \alpha$-マルテンサイトの経路を経て生ずる ことが Mangonon ら ${ }^{(5)}$ による電子顕微鏡観察により確か められている，以下このような事実をもとにして考察を進 めるが，本報告ではこれらの相をそれぞれ $\gamma ， \varepsilon^{\prime} ， \alpha^{\prime}$ で表わ し，変態を $\gamma \rightarrow \varepsilon^{\prime} ， \varepsilon^{\prime} \rightarrow \alpha^{\prime}$ のように表わすことにする.

今井ら ${ }^{(6)}$ の 17-8 ステンレス鋼に関する実験結果によれ ば $\gamma \rightarrow \varepsilon^{\prime} ， \varepsilon^{\prime} \rightarrow \alpha^{\prime}$ の各变態による体積膨張ひずみ $\epsilon_{0}$ はそれ 卆れ約 $\epsilon_{0}^{r \rightarrow \varepsilon^{\prime}}=-0.046, \epsilon_{0}^{\varepsilon^{\prime} \rightarrow \alpha^{\prime}}=0.060$ である.ところで Patel ら (2) の考え方に上れば, Ms 点温度を外部応力 $\sigma_{1}$ によって試験温度 (本実験の場合は室温) まで上昇させれば 変態を生ずると考えられる，この場合，大気圧下で変態を 生ぜしめるために外部から加えられるべき仕事量にくらべ $\tau ， P$ 気圧下では $\epsilon_{0} P$ だけ余分な仕事が必要となる。した がって $P$ 気圧下での $r \rightarrow \varepsilon^{\prime}$ 変態は大気圧下におけるよりも 促進されるし， $\varepsilon^{\prime} \rightarrow \alpha^{\prime}$ 変態は抑止されるはずである. それ で, 静水圧下で变形した場合は大気圧下よりも多くの $\varepsilon^{\prime}$ 相 が発生するが， $\varepsilon^{\prime}$ 相がさらに変態して $\alpha^{\prime}$ となる確率は大 気圧下より小さいから，本実験の場合は両者の効果が相殺

(4) Jochen von Fircks : Neue Hütte, 13(1968), 668.

(5) P. L. Mangonon and G. Thomas : Met. Trans., 1 (1970), 1577.

（6）今井, 泉山, 佐々木 : 金属学会誌, $27(1963), 513$. 
して結局 $\alpha^{\prime}$ の生成量が静水压下と大気圧下で差がなくな ったのであろう．ただし $\alpha^{\prime}$ へ変態せずに残留している $\varepsilon^{\prime}$ の量は静水圧下の方が多くなる。このことは前節で述べた 磁気測定やX線回折の結果に対応している.

\section{2. 静水王下における变形応力}

この試料を $12000 \mathrm{~kg} / \mathrm{cm}^{2}$ 中で引張試験したときの变形 応力の大気圧下の変形に対する增加は Fig.4 亿示したよ らであった．これによると変形応力の增加は，変形の初期 に大きな值を示すが，約 $15 \%$ ひずみ以上ではほぼ一定の 值(約 $12 \%$ ) となる．前に述べたように， $\alpha^{\prime}$ は約 $10 \%$ ひず み以上になってはじめて生成し，またひずみの增加に対す る $\alpha^{\prime}$ の増加は大気圧下, 高静水圧下共注ぼ同じであった。 したがって，この場合には大気圧下と $12000 \mathrm{~kg} / \mathrm{cm}^{2}$ 中で の変形応力を同一ひずみ量で比較する場合， $\alpha^{\prime}$ の量の差を 考虑する必要はない。

ところで Patel ら ${ }^{(2)}$ によれば $\gamma \rightarrow \alpha^{\prime}$ 变態に必要な外部 からの仕事 $U$ は大気圧下において

$$
U=V_{m}\left\{\frac{1}{2} \gamma_{0} \sigma_{1} \sin 2 \theta+\frac{1}{2} \epsilon_{0} \sigma_{1}(1+\cos 2 \theta)\right\}
$$

と表わされる．ここで $V_{m}$ は分子容， $\epsilon_{0}$ と $\gamma_{0}$ は変態によ る体積膨張ひずみとせん断ひずみ， $\theta$ は晶へき面の法線と 引張軸のなす角度, $\sigma_{1}$ は外部引張応力である. $P$ なる静 水圧下ではさらに $-\epsilon_{0} P$ 項が加わる. これが室温における 変態の化学的駆動力の不足分 $\Delta F_{\mathrm{R} . \mathrm{T}}$. に等しくなると変態 が生ずる．したがって次の関係が成立する。

$$
\begin{aligned}
\Delta F_{\mathrm{R} . \mathrm{T} .}= & V_{m}\left\{\frac{1}{2} r_{0} \sigma_{1} \sin 2 \theta+\frac{1}{2} \epsilon_{0} \sigma_{1}(1+\cos 2 \theta)\right\} \\
= & V_{m}^{\prime}\left\{\frac{1}{2} r_{0}\left(\sigma_{1}+\Delta \sigma_{1}\right) \sin 2 \theta+\frac{1}{2} \epsilon_{0}\left(\sigma_{1}+\Delta \sigma_{1}\right)\right. \\
& \left.(1+\cos 2 \theta)-\epsilon_{0} P\right\}
\end{aligned}
$$

ここで $V_{m}^{\prime}$ は $P$ 気圧下に批る分子容である. (2) 式の 示すように, $P$ 気圧下では $\epsilon_{0} P$ だけ余分な仕事を必要と し，そのため $\sigma_{1}$ が $\Delta \sigma_{1}$ だけ増加しなければならない。こ れから

$$
\begin{aligned}
\Delta \sigma_{1}+\left(1-\frac{V_{m}}{V_{m}^{\prime}}\right) \sigma_{1} & =\frac{P}{\frac{1}{2} \frac{r_{0}}{\epsilon_{0}} \sin 2 \theta+\frac{1}{2}(1+\cos 2 \theta)} \\
& =\frac{V_{m} \epsilon_{0} P}{\Delta F_{\mathrm{R} . \mathrm{T} .}} \sigma_{1}
\end{aligned}
$$

となる. 第 1 辺の括弧内の項 $1-V_{m} / V_{m}^{\prime}$ は第 3 辺の係数 $V_{m} \epsilon_{0} P / \Delta F_{\text {R.T. }}$ と比較して無視できるから

$$
\frac{\Delta \sigma_{1}}{\sigma_{1}}=\frac{V_{m} \epsilon_{0} P}{\Delta F_{\mathrm{R} . \mathrm{T}}}
$$

が求められる.

$\gamma \rightarrow \alpha^{\prime}$ 変態の場合, $\epsilon_{0}=0.014$ である. また $\gamma_{0}$ には今井 ら (6) の示した值 $\gamma_{0}=0.306$ を用いて大よその見当をつけ てみると (3) 式第 2 辺の分母は $\theta \simeq 44^{\circ}$ で最大となり，そ のときの $\Delta \sigma_{1}$ は $P=12000 \mathrm{~kg} / \mathrm{cm}^{2}$ に対して

$$
\Delta \sigma_{1} \simeq 10 \mathrm{~kg} / \mathrm{mm}^{2}
$$

となる. これは晶へき面が最も変態しやすい方位であっ $\tau, \Delta \sigma_{1}, \sigma_{1}$ が最小の場合に相当する. 本実験では $\alpha^{\prime}$ が最 初に生成する段階に括ける变形応力がこれに相当し, Figs.4, 5 からひずみ約 $10 \%$ で $\sigma_{1} \simeq 80 \mathrm{~kg} / \mathrm{mm}^{2}$ となる. したがって $\Delta \sigma_{1} / \sigma_{1} \simeq 12 \%$ となる.（4）式の示すようにこ の值は一定であって，ここで計算された值は Fig.4に示さ れている変形応力の增加の割合が一定となったところとほ ぼ一致している．以上の上うに，変形によって $\gamma \rightarrow \alpha^{\prime}$ 変態 を生ずる段階では，静水圧下と大気圧下の変形応力の差 は, $r \rightarrow \alpha^{\prime}$ 変態に必要な外部応力の周囲圧力による差で大 よそ与えられている。

次に, $r \rightarrow \alpha^{\prime}$ 変態の開始前の变形初期に拈ける静水圧下 の变形応力が，大気圧下での值にくらべて上に述べた一定 値よりさらに大きい理由については次のように考えられ る. 前節で Fig.5に関して述べたように，この段階では変 形は主として方りによって行なわれていると考えられる が，静水圧下では $\varepsilon^{\prime}$ 相の生成が大気圧下にくらべさかん に行なわれ，そのため $\gamma$ 相の加工硬化の進行が急激である ことが想像される. Mangonon ら(5) は18-8ステンレス鋼 の常温常圧下の $13 \%$ の変形で $\varepsilon^{\prime}$ 相が密に分布して発生す るのを観察している (引用文献 (5),Fig.4(b))。 $\varepsilon^{\prime}$ 相は $\gamma$ 相と比体積が異なるから両者の境界には応力場が発生す る. 高静水圧下でこのような $\varepsilon^{\prime}$ 相の分布が密にできれば 硬化の原因となるであろう.

以上に述べたことを模型的に示したものが Fig.6であ る. 図中 $0,12 \mathrm{~kb}$ はそれぞれ大気圧下および $12000 \mathrm{~kg} /$ $\mathrm{cm}^{2}$ 中に拊ける応力-ひずみ曲線を示している．大気圧下 においてはひずみの増加と共に $\gamma$ 相の加工硬化によって 変形応力が增加し，これが大気圧下において $r \rightarrow \alpha^{\prime}$ 変態を 生ずる応力 $\left(\sigma_{\alpha_{0}}\right)$ (最も低い応力で変態を生ずる晶へき面に ついて)に達すると $\alpha^{\prime}$ が生成されはじめる。 このときのひ

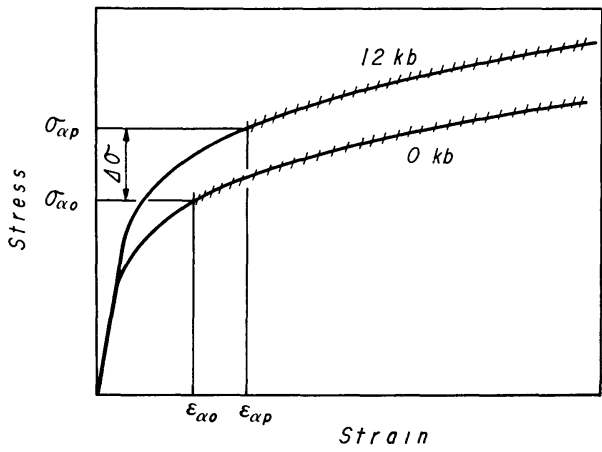

Fig.6 Schematic representation of the increase in flow stress under $12000 \mathrm{~kg} / \mathrm{cm}^{2} . \sigma_{\alpha_{0}}, \varepsilon_{\alpha_{0}}$ and $\sigma_{\alpha p}, \varepsilon_{\alpha p}$ represent the stresses and the strains where the stress-induced martensitic transformation starts at atmospheric pressure and under $12000 \mathrm{~kg} / \mathrm{cm}^{2}$, respectively. $\Delta \sigma$ shows an increase under $12000 \mathrm{~kg} / \mathrm{cm}^{2}$ in the tensile stress which is necessary to induce martensitic transformation 
ずみは $\varepsilon_{\alpha_{0}}$ である. 一方同じ材料を $12000 \mathrm{~kg} / \mathrm{cm}^{2}$ 中で変 形させると変形の初期において急速に $\varepsilon^{\prime}$ 相が生成して 相が硬化し，その硬化率は大気圧下の変形にくらべて大き い. $\gamma$ 相の加工硬化が進及変形応力が増大し，これが 12000 $\mathrm{kg} / \mathrm{cm}^{2}$ 中に护壮る $\gamma \rightarrow \alpha^{\prime}$ 変態に必要な応力 $\left(\sigma_{\alpha_{p}}=\sigma_{\alpha_{0}}+\right.$ $\Delta \sigma)$ に達すると $\alpha^{\prime}$ が生成されはじめる. このときのひず みは $\varepsilon_{\alpha p}$ となる. 図中応力-ひずみ曲線に 斜線を入れた部 分は $\alpha^{\prime}$ が生成される領域を示している。，一旦 $\alpha^{\prime}$ の形成が 開始すると，それ以後の変形では $r$ 相に打ける之り変形 に対する加工硬化 (変形応力) と, $r \rightarrow \alpha^{\prime}$ の応力誘起変態に 必要な変形応力はバランスしながら変形が進行する. した がって大気圧と $12000 \mathrm{~kg} / \mathrm{cm}^{2}$ 下の変形応力の差は $\gamma \rightarrow \alpha^{\prime}$ に必要な変形応力の差と一致すると考えてよい，本実験の 場合は前にも述べたように $\varepsilon_{\alpha_{0}} \simeq \varepsilon_{\alpha_{p}}$ であり， $\alpha^{\prime}$ 生成以後 の過程では同一のひずみに対しては $\alpha^{\prime}$ の量は大気圧中で も $12000 \mathrm{~kg} / \mathrm{cm}^{2}$ 下でもほぼ同じであった。 したがって変 形応力の差は (4) 式によって与えられその割合は一定の值 を示すことになる。

\section{3. 圧力変化に伴う変形応力の変化}

変形の途中で圧力を変化させたときの応力-ひずみ曲線 の変化はFigs.1〜3に示した通りであり，またこれに対応 するひずみ $\alpha^{\prime}$ 生成量の関係は Fig.5 亿示されている，以 下これについて考察を試みる。

従来, 筆者らの実験した純金属の結果 ${ }^{(7)}$ によれば, 圧 力変化に伴ら変形応力の変化は, 变形の機構が之りによる ものであり，圧力によってその機構に本質的な変化を生じ なければその材料の剛性率の圧力による変化 $\Delta G / G$ にほ ぼ等しい。この值はこの材料の場合求められていないが Bridgman $^{(8)}$ の鋼の結果から約 3\% であると思われる。 そ こで Fig.3には $3 \%$ の値をあわせて示した.

ところで Fig.5によれば本実験の場合，ひずみ約 10\% までは $\gamma \rightarrow \alpha^{\prime}$ 変態はおこらない。この場合にも $\gamma \rightarrow \varepsilon^{\prime}$ 変態 は生じているがこの変態によるせん断ひずみは小さく試料 の変形にはあまり寄与していないであろう，結局この範囲 では変形はほとんど之りのみで進行しており，変形応力の 圧力変化に伴万変化は $\Delta G / G$ の程度と思われる. Fig. 3 に おいて，ひずみ約 $10 \%$ 以下での応力変化は 0 ～ $4 \%$ であっ たが，これは大上そ $\Delta G / G$ の程度と考えてよいであろう。

ひずみが上記の範囲を越える段階では $\gamma \rightarrow \alpha^{\prime}$ 変態が生 じ，変形はシりとマルテンサイト変態との両方によって行 なわれる。 また変形途中で圧力を変化させると $\alpha^{\prime}$ の生成 率が変化する．すなわちこの場合には周囲圧力の変化によ って変形の機構が本質的に変化する. したがって上で用い たような純金属で得られた結果は適用することができな w.

（7）小口, 吉田, 信木 : 金属学会誌, 35(1971)，371, など.

(8) P.W.Bridgman: The Physics of High Pressure, G.Bell and Sons, London, (1952), 386.
いま, $\gamma \rightarrow \alpha^{\prime}$ 変態を生ずるひずみの段階で圧力を 12000 $\mathrm{kg} / \mathrm{cm}^{2}$ から大気圧へ変化した場 合について考えてみる. 高静水圧中で変形したものは $\gamma \rightarrow \alpha^{\prime}$ 変態を生じているが IV.1. で述べたように $\varepsilon^{\prime}$ 相が余分に存在している.これを 大気圧下で再負荷していくと，残存している $\varepsilon^{\prime}$ 相は応力 が大気圧下に批りる $\varepsilon^{\prime} \rightarrow \alpha^{\prime}$ 变態に必要な值に達すれば変 態して $\alpha^{\prime}$ になる.このときの応力を同じ大気圧下での $\gamma \rightarrow$ $\alpha^{\prime}$ 变態に必要な応力と比較すると, 大気圧下と高静水圧 下では $\alpha^{\prime}$ 相はひずみの増加に対してほぼ同量生成されて いるから,この $\varepsilon^{\prime} \rightarrow \alpha^{\prime}$ 変態に必要な応力は大気圧下で同じ ひずみまで変形した場合 $\left(\gamma \rightarrow \alpha^{\prime}\right.$ 变態) より低くなることに なる.ささらに, この応力では汇りは発生できないから, 変 形はまずもっぱら $\varepsilon^{\prime} \rightarrow \alpha^{\prime}$ 変態によって行なわれ，ひずみあ たりの $\alpha^{\prime}$ 生成率は大きくなる。ささらに変形が進むといず れ過鄱の $\varepsilon^{\prime}$ 相は消費されてあとは $\gamma \rightarrow \alpha^{\prime}$ 変態を生ずるが， $\varepsilon^{\prime} \rightarrow \alpha^{\prime}$ 変態が急速に行なわれたことによって $\alpha^{\prime}$ が多く生 成されているからこの段階以降の加工硬化は大きくなるも のと思われる。

次に, 圧力を大気圧から $12000 \mathrm{~kg} / \mathrm{cm}^{2}$ へ変化させた場 合は次のように考えられる。気氖下で变形させた場合， 試料の中には残留する $\varepsilon^{\prime}$ 相はほとんぞないが，これを $12000 \mathrm{~kg} / \mathrm{cm}^{2}$ 中で再負荷すると変形初期に急速に $\varepsilon^{\prime}$ 相が 生成され，これによってr相の地が急激に加工硬化する. このようにして試料中の応力が $12000 \mathrm{~kg} / \mathrm{cm}^{2}$ に淤るる $r \rightarrow \alpha^{\prime}$ 变態に必要な応力に達するとそれ以降は変態と方り が共存して変形が生ずる．この応力は圧力上昇前の変形応 力より, $12000 \mathrm{~kg} / \mathrm{cm}^{2}$ 中で $\gamma \rightarrow \alpha^{\prime}$ 変態を生ずるに必要な 応力増加分だけ高いはずであるから，Fig.3に示されるよ らな結果となる。

以上, 高静水圧下で変形した場合の, 変形初期における 大きな加工硬化と， $\alpha^{\prime}$ が生成してから後に圧力を大気圧 におろしてから再負荷したときの変形応力の低下の現象を いずれも $\varepsilon^{\prime}$ 相の存在によるものとして説明した。ささらに この点を確かめるために以下のような実験を行なった。す なわちそれぞれひずみ約 7，20，30\% まで大気圧下および $12000 \mathrm{~kg} / \mathrm{cm}^{2}$ の静水圧下で引張試験し，これらの試料を

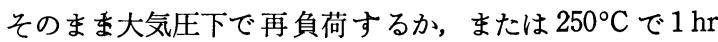
焼鈍してから再負荷して引張試験した。 その結果を Fig.7 に示す．Fig.7 の結果を観察すると，最初に高静水圧下で 引張变形した試料を大気圧下で再負荷した際の，ひずみが 小さい段階の加工硬化およびひずみが大きい段階での応力 低下の両現象は焼鈍によって消隇してしまうことがわか る. Mangonon ら ${ }^{(9)}$ によると 18-8 ステンレス鋼の低温変 形によって生ずる $\varepsilon^{\prime}$ 相は $200^{\circ} \mathrm{C}$ の熱処理によって大部分 $\gamma$ 相にもどってしまうとされているから，この場合も生成 していた $\varepsilon^{\prime}$ 相は $250^{\circ} \mathrm{C}, 1 \mathrm{hr}$ の熱処理によって消減したも のと解釈できる. ひずみ $30 \%$ の場合，焼鈍後の応力上昇

(9) P. L. Mangonon and G. Thomas : Met. Trans., 1 (1970), 1587. 


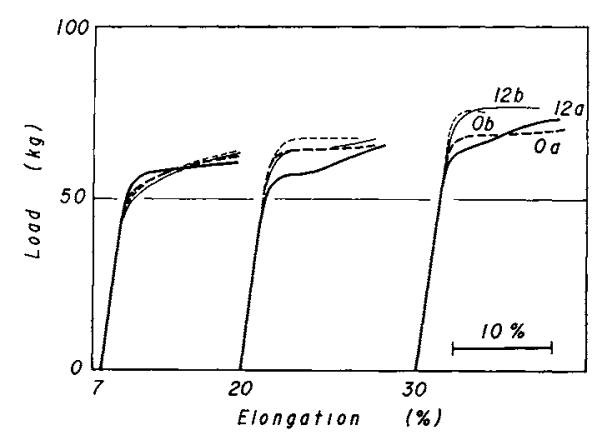

Fig.7 Load-elongation relations at atmospheric pressure for the specimens pre-strained at atmospheric pressure (0a) and under $12000 \mathrm{~kg} / \mathrm{cm}^{2}(12 \mathrm{a}) .0 \mathrm{~b}$ and $12 \mathrm{~b}$ represent the same relations after annealing at $250^{\circ} \mathrm{C}$ for $1 \mathrm{hr}$

は，大気压下变形，静水压下変形のいずれの試料について も同様に抗こっているからこれは $\varepsilon^{\prime}$ 相の生成とは無関 係のひずみ時效的な現象によるのであろう。

\section{V. 結 言}

加工誘発変態を生ずる材料の変形挙動に及ぼす静水任の 影響を謂べるために，オーステナイト組織をるつ 18-8 ス テンンス鋼を大気圧下拉よび $12000 \mathrm{~kg} / \mathrm{cm}^{2}$ 中で空温に拉 いて引張試験し次のような結果を得た。
(1) $12000 \mathrm{~kg} / \mathrm{cm}^{2}$ の静水圧下に打いて液圧処理しても, その効果は認められない。

(2) 磁気的方法で $\alpha$-マルテンサイトの生成量を調べた 結果, $12000 \mathrm{~kg} / \mathrm{cm}^{2}$ 中, 大気压下共ひずみ約 $10 \%$ までは

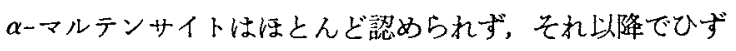
みと共に増加したがその生成量とひずみ量の関保は両圧力 中で滦涪同じであった、また，12000 kg/ $\mathrm{cm}^{2}$ 中で变形し た場合にはと-マルテンサイトが残留していることがX 線 的に認められた。

(3) 一定圧力下で変形した場合, $12000 \mathrm{~kg} / \mathrm{cm}^{2}$ 中での 変形応力の大気圧下での值に対する増加は変形初期で大き く、ひずみの増加と共に減少して約 15\%ひずみ以降で一 定の約 $12 \%$ となる.

(4) 変形の途中で生力を大気压と $12000 \mathrm{~kg} / \mathrm{cm}^{2}$ の間で 変化させた場合，変形応力はひずみの小さい範囲では0

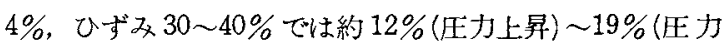
降下)それそ゚れ変化する。

(5)上の(3)，(4)に述べた現象は次のような事実によ り説明できる。すなわち，高静水左下では変形の初期に急 速にยーマルテンサイトが生成され大気王下にくらべ加工 硬化が大きい、しかしひずみの大きい範井においては試料 を大気圧下で再負荷した場合，このと-マルテンサイトは 低い引張応力下で $\alpha$-マルテンサイトに変態する. 